\title{
EFFECTS OF VARIOUS ELICITORS \\ ON THE ACCUMULATION AND SECRETION OF SPIROKETAL ENOL ETHER DIACETYLENES IN FEVERFEW HAIRY ROOT CULTURE
}

\author{
ANNA STOJAKOWSKA ${ }^{1}$, JAN BURCZYK ${ }^{2}$, WANDA KISIEL ${ }^{1}$, \\ MARIA ZYCH ${ }^{2}$, ANNA BANAŚ ${ }^{2}$, TERESA DUDA ${ }^{2}$ \\ ${ }^{1}$ Department of Phytochemistry, Institute of Pharmacology \\ Polish Academy of Sciences \\ Smętna 12, 31-343 Kraków, Poland \\ e-mail: stoja@if-pan.krakow.pl \\ 2 Medical University of Silesia \\ Department of Pharmacognosy and Phytochemistry \\ Jagiellońska 4, 41-200 Sosnowiec, Poland
}

(Received: November 20, 2006. Accepted: January 31, 2007)

\begin{abstract}
In a hairy root culture of Tanacetum parthenium treated with yeast extract (YE), silver nitrate $\left(\mathrm{AgNO}_{3}\right)$ and microalgal glycoproteins (MGPS), contents of four spiroketal enol ether type diacetylenes were measured. The elicitors transiently reduced contents of three constitutive spiroketal enol ethers and selectively enhanced accumulation of $\mathrm{cis}-\mathrm{C}_{13}$-spiroketal enol ether epoxide ((E)-3,4-epoxy-2-(2,4-hexadiynylidene)-1,6-dioxaspiro[4.4]nonane) in the roots. The most abundant formation of $\mathrm{cis}$ - $\mathrm{C}_{13}$-spiroketal enol ether epoxide was observed after $48-96 \mathrm{~h}$ of $\mathrm{AgNO}_{3}$ treatment and $96 \mathrm{~h}$ of YE treatment (over 3-fold increase compared with the control). The applied elicitors caused enhanced liberation of $\mathrm{cis}-\mathrm{C}_{13}$-spiroketal enol ether epoxide to the culture medium. The results show that diacetylene accumulation pattern in the elicited hairy roots is affected in a similar manner, irrespectively of the elicitor applied.
\end{abstract}

KEY WORDS: acetylenes, elicitors, hairy roots, spiroketal enol ethers, Tanacetum parthenium, tonghaosu.

\section{INTRODUCTION}

Diacetylenes of spiroketal enol ether type are known as secondary metabolites synthesized by plants of Anthemideae tribe (Asteraceae) (Christensen 1992). The compounds are constitutive metabolites of feverfew (Tanacetum parthenium (L.) Sch. Bip.), present both in roots and aerial parts of the plant (Bohlmann and Zdero 1982). They are biologically active as smooth muscle relaxants (Breinlich and Scharnagel 1968), insect antifeedants (Tada and Chiba 1984; Chen et al. 2004a), insecticides (Chen et al. 2004b), inhibitors of rat mast cells degranulation (Miller et al. 1996) and nitric oxide production in lipopolysaccharideactivated macrophages (Yoshikawa et al. 2000). Cis- $\mathrm{C}_{14}{ }^{-}$ -spiroketal enol ether epoxide was found to inhibit TPA-induced $\mathrm{O}_{2}{ }^{-}$generation in differentiated HL-60 cells, two times stronger than genistein (Nakamura et al. 1998). The same compound and its derivative appeared to be effective chemopreventers of mouse skin carcinogenesis (Nakamura et al.
1999). Recently, a report on inhibition of $N F-\kappa B$ activation and expression of inflammatory mediators by diacetylene spiroketals has been published (Calzado et al. 2005). Moreover, cis- and trans- $\mathrm{C}_{13}$-spiroketal enol ethers (also known as tonghaosu) as potent inhibitors of some human cytochrome P450 enzymes may interfere with metabolism of drugs and other xenobiotics in human body (Ganzera et al. 2006).

From a transformed root culture of feverfew four diacetylene spiroketal enol ethers and two coumarins were isolated (Stojakowska and Kisiel 1997a; Kisiel and Stojakowska 1997; Stojakowska et al. 2002). The roots of clone M2 accumulated trans- $\mathrm{C}_{13}$-spiroketal enol ether ( $Z$ )-2-(2,4-hexadiynylidene)-1,6-dioxaspiro[4.4]non-3-ene) (1) as a major constituent (structures shown at Fig. 1). Moreover, $(E)$ -3,4-epoxy-2-(2,4-hexadiynylidene)-1,6-dioxaspiro[4.4]nonane (2), cis form of 1, i.e. ((E)-2-(2,4-hexadiynylidene)1,6-dioxaspiro[4.4]non-3-ene) (3), and trans- $\mathrm{C}_{14}$-spiroketal enol ether ( $(Z)-2-(2,4$-hexadiynylidene)-1,6-dioxaspiro[4.5]dec-3-ene) (4) were isolated from roots of clone M2. 


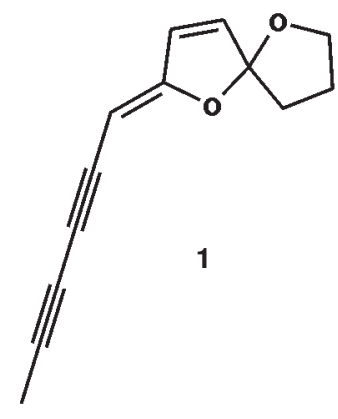

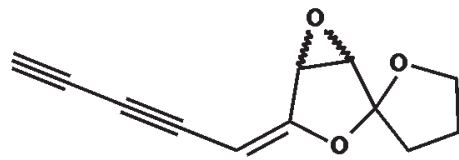

2

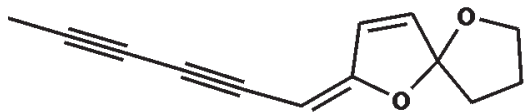

3

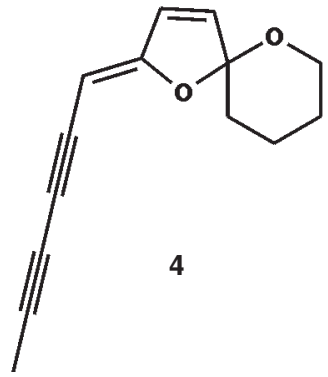

Fig. 1. Structures of spiroketal enol ether type diacetylenes (1-4) isolated from transformed roots of Tanacetum parthenium.
An influence of exogenously applied SA and MJ, both being endogenous signal molecules implicated in eliciting plant resistance to pathogens and herbivores (Thomma et al. 1998; Schenk et al. 2000; Ozawa et al. 2000), on accumulation pattern of spiroketal enol ether diacetylenes in hairy root cultures of feverfew has been studied previously (Stojakowska et al. 2002). MJ treatment caused an about two fold increase of spiroketal enol ether type diacetylenes 1-4 contents in the roots whereas salicylic acid transiently reduced contents of major constitutive spiroketal enol ethers (1, 3 and 4) and selectively enhanced accumulation of cis- $\mathrm{C}_{13}$-spiroketal enol ether epoxide (2). In a search for the factors stimulating diacetylene production in the hairy roots of feverfew some biotic and abiotic elicitors were investigated in the present study.

\section{MATERIAL AND METHODS}

\section{Plant material}

T. parthenium root clone M2, transformed with Agrobacterium rhizogenes LBA 9402, was established and maintained as described elsewhere (Stojakowska and Kisiel 1997b).

\section{Preparation of MGPS from microalgal culture}

Microalgal glycoproteins, high molecular glucosamine containing cell wall biopolymers (Burczyk et al. 1999), were isolated from 30-day-old culture of Scenedesmus obliquus strain 633 cultivated mixotrophically in medium I of Kessler and Czygan (1970) enriched with $5 \mathrm{~g} \mathrm{l}^{-1}$ of glucose under the conditions described previously (Burczyk 1979). Algal cells and maternal cell walls were sedimented by centrifugation at $800 \mathrm{~g}$ for $10 \mathrm{~min}$ at $4^{\circ} \mathrm{C}$. Glycoproteins were precipitated from the supernatant with tannin solution (Mejbaum-Katzenellenbogen 1959) and were liberated from the precipitate by addition of caffeine (Mejbaum-Katzenellenbogen et al. 1959). The procedure was completed by freezing the precipitate with caffeine at $-20^{\circ} \mathrm{C}$ and dissolving the liberated glycoproteins in a small quantity of distilled water. From the solution MGPS were precipitated with acetone and the remaining solvent was removed under the reduced pressure. The MGPS gave crossreaction with rabbit antibodies prepared against cell walls of Scenedesmus obliquus.

\section{Preparation of elicitor stock solutions}

Stock solution of silver nitrate $(33.3 \mathrm{mM})$ was prepared by dissolving $56.6 \mathrm{mg}$ of $\mathrm{AgNO}_{3}$ (POCh S.A., Gliwice, Poland) in $10 \mathrm{ml}$ of sterile distilled water. Stock solutions of YE and MPGS were prepared by dissolving $500 \mathrm{mg}$ of yeast extract (Sigma, St. Louis, MO, USA) and $100 \mathrm{mg}$ of MPGS, respectively, in $5 \mathrm{ml}$ of sterile distilled water. The solutions were filtered through a membrane filter (pore size: $0.2 \mu \mathrm{m})$ and stored below $-20^{\circ} \mathrm{C}$.

\section{Elicitation experiments}

Roots of clone M2 (0.3 g fresh weight) were inoculated into $250 \mathrm{~mL}$ Erlenmayer flasks, each containing $30 \mathrm{ml}$ of a modified MS (Murashige and Skoog 1962) liquid medium (half strength macronutrients). The cultures were kept at $25^{\circ} \mathrm{C}$, with $16 \mathrm{~h}$ photoperiod $\left(20 \mu \mathrm{mol} \mathrm{m} \mathrm{m}^{-2} \mathrm{~s}^{-1}\right.$, cool white fluorescent tubes), on a gyrotory shaker at 110 r. p. m.

The stock solution of $\mathrm{AgNO}_{3}(90 \mu \mathrm{l})$, YE $(240 \mu \mathrm{l})$ or MGPS $(300 \mu \mathrm{l})$ was added to the flasks, containing 10 day old cultures, to reach the final concentration of $0.1 \mathrm{mM}$ $\mathrm{AgNO}_{3}, 0.08 \% \mathrm{YE}$ or $0.02 \%$ MPGS in the nutrient medium. To the controls adequate volume of sterile distilled water was added. Samples of the treated roots and the corresponding controls (each in duplicate), as well as spent culture media samples, were collected after 48 and 96 hours of the treatment. Root samples were stored frozen $\left(-85^{\circ} \mathrm{C}\right)$ until use and their dry weight was recorded after 

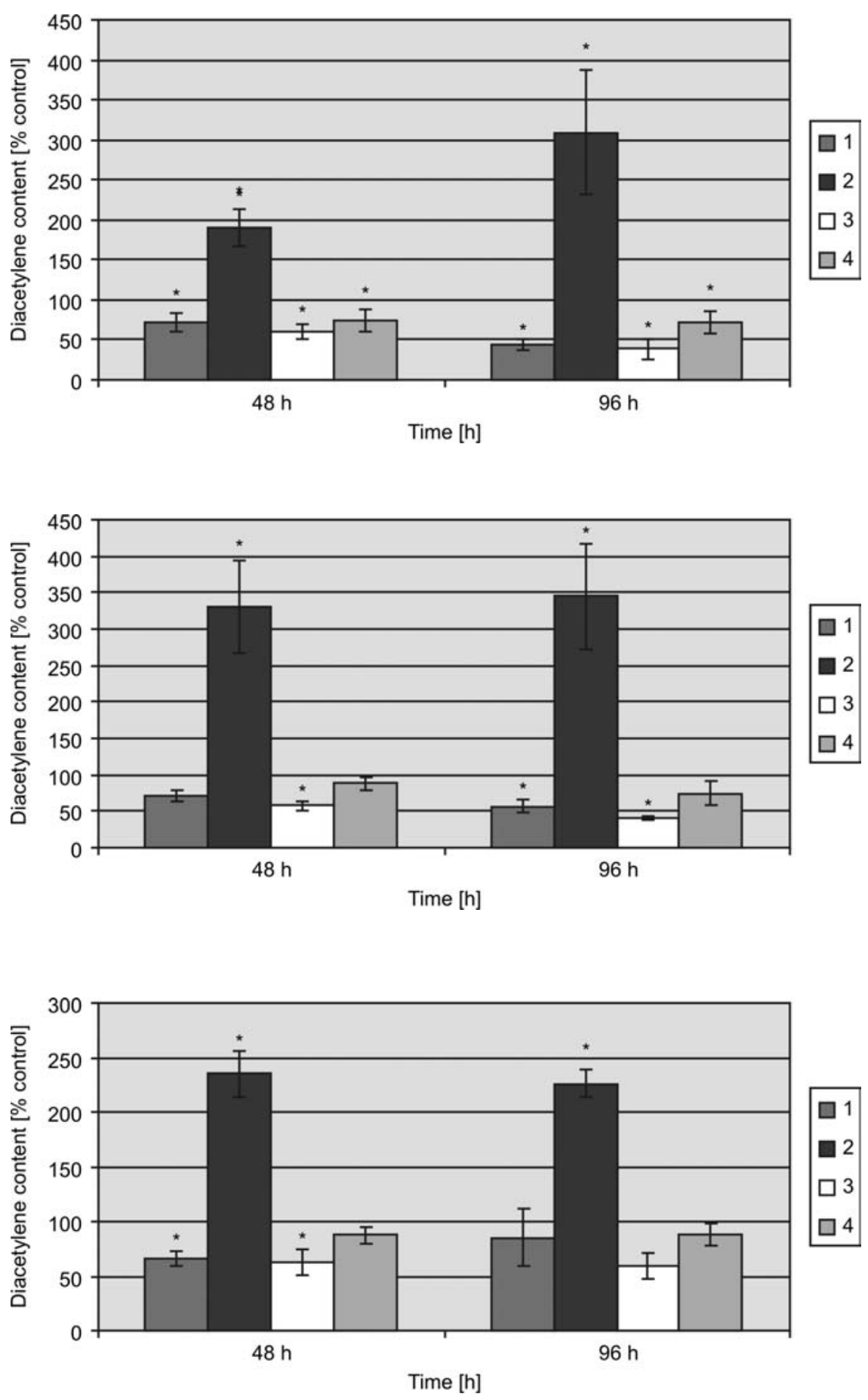

Fig. 2. Changes in diacetylene contents in $T$. parthenium hairy roots induced by $0.08 \%$ YE in the nutrient medium. Data are means of four measurements. Bars represent s.d. Approximate control values ( $\mathrm{mg} \mathrm{g}^{-1}$ dry weight): 48 h: $\mathbf{1}-5.36, \mathbf{2}-1.12, \mathbf{3}-2.29, \mathbf{4}$ $1.35 ; 96$ h: $\mathbf{1}-6.08, \mathbf{2}-0.94, \mathbf{3}-2.41,4-$ 1.09 .

Fig. 3. Changes in diacetylene contents in $T$. parthenium hairy roots induced by $0.1 \mathrm{mM}$ $\mathrm{AgNO}_{3}$ in the nutrient medium. Data are means of four measurements. Bars represent s.d. Approximate control values ( $\mathrm{mg} \mathrm{g}^{-1}$ dry weight): 48 h: $\mathbf{1}-4.87, \mathbf{2}-1.60, \mathbf{3}-2.00, \mathbf{4}$ $-0.95 ; 96$ h: $\mathbf{1}-6.35, \mathbf{2}-1.57, \mathbf{3}-2.47, \mathbf{4}-$ 1.25 .

Fig. 4. Changes in diacetylene contents in $T$. parthenium hairy roots induced by $0.02 \%$ MGPS in the nutrient medium. Data are means of four measurements. Bars represent s.d. Approximate control values ( $\mathrm{mg} \mathrm{g}^{-1}$ dry weight): 48 h: $\mathbf{1}-3.20, \mathbf{2}-1.11, \mathbf{3}-1.29,4$ -0.87 ; 96 h: $\mathbf{1}-4.62, \mathbf{2}-1.55, \mathbf{3}-1.90, \mathbf{4}-$ 1.22 .

lyophilisation. Samples of culture media were immediately used for phytochemical analysis. Each experiment was repeated at least once within the following 6 months.

\section{Sample preparation}

Lyophilised roots $(0.25 \mathrm{~g})$ were extracted three times with $10 \mathrm{ml}$ of hexane-acetone mixture (1:1), at room temperature. The combined extracts were evaporated in vacuo. The dry residue was dissolved in $1 \mathrm{ml}$ of acetonitrile and filtered through a membrane filter $(0.2 \mu \mathrm{m})$.

Culture medium $(50 \mathrm{ml})$ was extracted three times with $10 \mathrm{ml}$ of dichloromethane. Pooled organic fractions were evaporated in vacuo and the residue was dissolved in 0.5 $\mathrm{ml}$ of acetonitrile and centrifuged at 11,000 $\mathrm{g}$ (5 min).

\section{Quantification of diacetylenes}

An analysed sample $(20 \mu \mathrm{l})$ was injected into a RadialPak, $\mu$ Bondapak C18 $(8 \times 100 \mathrm{~mm})$ cartridge (Waters Associates) coupled with a Waters 2487 Dual $\lambda$ Absorbance Detector, operating at $224 \mathrm{~nm}$ and $315 \mathrm{~nm}$. Water-acetonitrile mixture (11:9, v/v), at a flow rate of $2 \mathrm{ml} \mathrm{min}^{-1}$, was employed as a solvent system. Peak areas were measured at 315 $\mathrm{nm}$ (compounds 1, 3 and 4) and $224 \mathrm{~nm}$ (compound 2).

\section{Statistics}

All experiments were carried out in duplicate and were repeated at least once. The results shown in Figures 2-4 are means of four measurements, derived from different experiments. A paired t-test of significance $(\mathrm{P}<0.05)$ was performed for the means of control and treated groups (Micro- 
TABLE 1 . Final dry weight of feverfew hairy roots (g flask ${ }^{-1} \pm$ s.d.) from the elicited and control cultures.

\begin{tabular}{ccccc}
\hline \multirow{2}{*}{$\begin{array}{c}\text { Treatment } \\
\text { duration }\end{array}$} & \multicolumn{4}{c}{ Treatment applied } \\
\cline { 2 - 5 } & YE & $\mathrm{AgNO}_{3}$ & MGPS & Control \\
\hline $48 \mathrm{~h}$ & $0.26 \pm 0.02$ & $0.17 \pm 0.01$ & $0.20 \pm 0.03$ & $0.22 \pm 0.02$ \\
$96 \mathrm{~h}$ & $0.27 \pm 0.01$ & $0.17 \pm 0.01$ & $0.23 \pm 0.04$ & $0.24 \pm 0.03$
\end{tabular}

soft Excel 2000). Statistically significant differences are marked by asterisk. Bars represent standard deviation.

\section{RESULTS AND DISCUSSION}

The effects of elicitors on biomass accumulation and production of spiroketal enol ethers in the feverfew hairy root culture were shown in Table 1 and Figs 2-4. YE significantly improved growth of the roots $48 \mathrm{~h}$ after elicitation, but $96 \mathrm{~h}$ after initiation of the experiment there was no significant difference in dry weight between the treated and the control roots. Silver ions significantly reduced root growth $48 \mathrm{~h}$ and $96 \mathrm{~h}$ after the elicitation. Dry weights of the treated roots were, respectively, 20\% and 29\% lower than those of the corresponding controls. MPGS did not affect root growth throughout the experiment.

The elicitors exerted a surprisingly uniform influence on diacetylene accumulation pattern in the examined root culture. They significantly reduced the contents of $\mathbf{1}$ and 3-4 and induced accumulation of compound 2. In YE treated roots the accumulation of $\mathbf{2}$ was higher at $96 \mathrm{~h}(307 \%$ of control) than at $48 \mathrm{~h}$ (183\% of control), after initiation of the experiment (Fig. 2). Elicitation with $100 \mu \mathrm{M} \mathrm{AgNO}_{3}$ resulted in overaccumulation of $\mathbf{2}$ (more than three fold over the control value) throughout the course of the experiment (Fig. 3). Roots treated with MGPS showed maximum accumulation of 2 (240\% control) $48 \mathrm{~h}$ after initiation of experiment (Fig. 4). Contents of diacetylenes in the nutrient media were also studied. In the control cultures the media contain very low concentrations of the monitored compounds (less than $2 \mathrm{mg} \mathrm{l}^{-1}$ ). Of these 1 was the major compound. Compounds $\mathbf{2}$ and $\mathbf{4}$ were not detected in the control media. Only $\mathrm{Ag} \mathrm{NO}_{3}$ treatment caused increased accumulation of 1-4 in the nutrient medium. The total content, however, did not exceed $10 \%$ of that found in the roots. Elicitation with YE and MGPS caused liberation of $\mathbf{2}$ to the culture medium.

In our previous study (Stojakowska et al. 2002), we reported on enhanced accumulation of 1-4 in the hairy roots of feverfew induced by MJ. In the roots treated by SA enhanced accumulation of $\mathbf{2}$ was accompanied with diminished concentrations of the remainig diacetylenes. Biotic and abiotic elicitors applied in the course of the present study modulate diacetylene accumulation in feverfew hairy roots in a salicylate-like not jasmonate-like fashion.

Elicitation of polyacetylene production in plant tissue cultures has been extensively studied in hairy root cultures of Tagetes patula L. and Ambrosia sp. In the hairy roots of T. patula treated with cell wall extract of Fusarium oxysporum conversion of 5-(3-buten-1-yl)-2,2'-bithienyl (BBT) to its hydroxyderivatives and their acetyl esters of antifungal activity was observed (Arroo et al. 1995). Both pathogenic and non-pathogenic fungi (Mukundan and Hjortso 1990), as well as a microalgal preparation (Rao et al. 2001) were successfully used to enhance accumulation of BBT and its derivatives in hairy roots of T. patula. A 6-8 fold increase in the content of thiarubrine $\mathrm{A}$, an antimicrobial polyacetylene, was induced in hairy roots of Ambrosia artemisiifolia by both autoclaved fungal cell wall filtrates and abiotic elicitor - vanadyl sulfate (Bhagwath and Hjortso 2000). As cis- $\mathrm{C}_{13}$-spiroketal enol ether epoxide has been selectively accumulated in $T$. parthenium hairy roots upon elicitation, its role as secondary metabolite involved in chemical defence of the plant could be deduced. Antimicrobial activity of the compound should be of interest. MGPS from Scenedesmus obliquus, in the concentration tested, appeared to affect secondary metabolism of $T$. parthenium hairy roots similarly to classical elicitors with no effect on root growth.

\section{LITERATURE CITED}

ARROO R.R.J., DE BROUWER A.P.M., CROES A.F., WULLEMS G.J. 1995. Thiphene interconversion in elicitor-treated roots of Tagetes patula L. Plant Cell Rep.15: 133-137.

BHAGWATH S.G., HJORTSØ M.A. 2000. Statistical analysis of elicitation strategies for thiarubrine A production in hairy root cultures of Ambrosia artemisiifolia. J. Biotechnol. 80: 159-167.

BOHLMANN F., ZDERO C. 1982. Sesquiterpene lactones and other constituents from Tanacetum parthenium. Phytochemistry 21: 2543-2549.

BREINLICH J., SCHARNAGEL K. 1968. Pharmakologische Eigenschaften des EN-IN-Dicycloäthers aus Matricaria chamomilla. Arzneim.-Forsch. 18: 429-431.

BURCZYK J. 1979. Carotenoids localised in the cell wall of Chlorella and Scenedesmus (Chlorophyceae). Bull. Acad. Pol. Sci. Ser. Sci. Biol. 27: 13-18.

BURCZYK J., ŚMIETANA B., TERMIŃSKA-PABIS K., ZYCH M., KOWALOWSKI P. 1999. Comparison of nitrogen content amino acid composition and glucosamine content of cell walls of various chlorococcalean algae. Phytochemistry 51: 491-497.

CALZADO M.A., SCHMID LÜDI K., FIEBICH B., BEN-NERIAH Y., BACHER S., MUNOZ E, BALLERO M., PROSPERINI S., APPENDINO G., LIENHARD SCHMITZ M. 2005. Inhibition of NF- $\kappa B$ activation and expression of inflammatory mediators by polyacetylene spiroketals from Plagius flosculosus. Biochim. Biophys. Acta 1729: 88-93.

CHEN L., XU H.-H., YIN B.-L., XIAO C., HU T.-S., WU Y.-L. 2004a. Synthesis and antifeeding activities of tonghaosu analogues. J. Agric. Food Chem. 52: 6719-6723.

CHEN L., XU H.-H., YIN B.-L., XIAO C., HU T.-S., WU Y.-L. 2004b. Synthesis and biological activity of tonghaosu analogs containing phenoxy-phenyl moiety. Chin. J. Chem. 22: 984$-989$.

CHRISTENSEN L.P. 1992. Acetylenes and related compounds in Anthemideae. Phytochemistry 31: 7-49.

GANZERA M., SCHNEIDER P., STUPPNER H. 2006. Inhibitory effects of the essential oil of chamomile (Matricaria recutita L.) and its major constituents on human cytochrome P450 enzymes. Life Sci. 78: 856-861.

KESSLER E., CZYGAN F.C. 1970. Physiologische und biochemische Beiträge zur Taxonomie der Gattung Chlorella. IV. Verwertng organischer Stickstoffverindungen. Arch. Mikrobiol. 70: 211-216.

KISIEL W., STOJAKOWSKA A. 1997. A sesquiterpene coumarin ether from transformed roots of Tanacetum parthenium. Phytochemistry 46: 515-516.

MEJBAUM-KATZENELLENBOGEN W. 1959. Insoluble protein-tannin compounds. Acta Bioch. Pol. 6: 375-383.

MEJBAUM-KATZENELLENBOGEN W., DOBRYSZYCKA W., BOGUSŁAWSKA-JAWORSKA J., MORAWIECKA B. 
1959. Regeneration of protein from insoluble protein-tannin compounds. Nature 184: 1799-1800.

MILLER T., WITTSTOCK U., LINDEQUIST U., TEUSCHER E. 1996. Effects of some components of the essential oil of chamomile, Chamomilla recutita, on histamine release from rat mast cells. Planta Med. 62: 60-61.

MUKUNDAN U., HJORTSØ M. 1990. Thiophene accumulation in hairy roots of Tagetes patula in response to fungal elicitors. Biotechnol. Lett. 12: 609-614.

MURASHIGE T., SKOOG F. 1962. A revised medium for rapid growth and bioassays with tobacco tissue cultures. Physiol. Plant. 15: 473-497.

NAKAMURA Y., KAWAMOTO N., OHTO Y., TORIKAI K., MURAKAMI A., OHIGASHI H. 1999. A diacetylenic spiroketal enol ether epoxide, AL-1, from Artemisia lactiflora inhibits 12-O-tetradecanoylphorbol-13-acetate-induced tumor promotion possibly by suppression of oxidative stress. Cancer Lett. 140: 37-45.

NAKAMURA Y., OHTO Y., MURAKAMI A., JIWAJINDA S., OHIGASHI H. 1998. Isolation and identification of acetylenic spiroketal enol ethers from Artemisia lactiflora as inhibitors of superoxide generation induced by a tumor promoter in differentiated HL-60 cells. J. Agric. Food Chem. 46: 5031-5036.

OZAWA R., ARIMURA G., TAKABAYASHI J., SHIMODA T., NISHIOKA T. 2000. Involvement of jasmonate- and salicylate-related signaling pathways for the production of specific herbivore-induced volatiles in plants. Plant Cell Physiol. 41: 391-398.

RAO S.R., TRIPATHI U., SURESH B., RAVISHANKAR G.A. 2001. Enhancement of secondary metabolite production in hairy root cultures of Beta vulgaris and Tagetes patula under the influence of microalgal elicitors. Food Biotechnol. 15: 35-46.
SCHENK P.M., KAZAN K., WILSON I., ANDERSON J.P., RICHMOND T., SOMERVILLE S.C., MANNERS J.M. 2000. Coordinated plant defence responses in Arabidopsis revealed by microarray analysis. Proc. Natl Acad. Sci. USA 97: 11655-11660.

STOJAKOWSKA A., KISIEL W. 1997a. Acetylenes in Agrobacterium rhizogenes transformed root culture of Tanacetum parthenium. Pol. J. Chem. 71: 509-512.

STOJAKOWSKA A., KISIEL W. 1997b. Production of parthenolide in organ cultures of feverfew. Plant Cell Tiss. Org. Cult. 47: 159-162.

STOJAKOWSKA A., MALARZ J., KISIEL W. 2002. Salicylate and methyl jasmonate differentially influence diacetylene accumulation patterm in transformed roots of feverfew. Plant Sci. 163: 1147-1152.

TADA M., CHIBA K. 1984. Novel plant growth inhibitors and an insect antifeedant from Chrysanthemum coronarium. Agric. Biol. Chem. 48: 1367-1369.

THOMMA B.P.H.J., EGGERMONT K., PENNINCKX I.A. M.A., MAUCH-MANI B., VOGELSANG R., CAMMUE B.P.A., BROEKAERT W.F. 1998. Separate jasmonate-dependent and salicylate-dependent defense-response pathways in Arabidopsis are essential for resistance to distinct microbial pathogens. Proc. Natl Acad. Sci. USA 95: 15107-15111.

YOSHIKAWA M., MORIKAWA T., TOGUHIDA I., HARIMA S., MATSUDA H. 2000. Medicinal flowers. II. Inhibitors of nitric oxide production and absolute stereostructures of five new germacrane-type sesquiterpenes, kikkanols D, D monoacetate, E, F, and F monoacetate from the flowers of Chrysanthemum indicum L.. Chem. Pharm. Bull. 48: 651-656. 